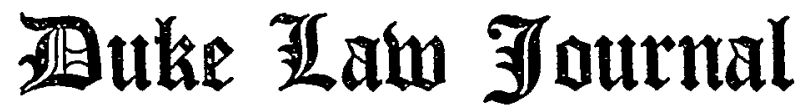

VOLUME 1963

SUMMER

NUMBER 3

\section{DEDICATION OF THE NEW DUKE LAW SCHOOL BUILDING}

\author{
EARL WARREN*
}

I AM very happy to be on your campus today. It is my first visit

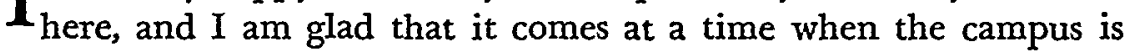
adorned in its beautiful Spring attire. I am also happy that the occasion of my visit here is the dedication of another in the galaxy of your beautiful buildngs, and I am pleased, of course, that the new building should be one dedicated to the law.

In recent years, it has been my privilege to participate in a number of such ceremonies, and on each such occasion I add to my confidence in the future of our institutions and the well-being of our people. The realization that for generations to come young Americans will there acquire an inspiration from the law, and thereafter, throughout their professional lives as practitioners, judges and legal scholars, will leave their marks on the standards of justice under which all our people live lends excitement to the occasion. Also, it gives one a warm feeling of gratitude to those who, having conceived the idea, labored to bring it to fruition with such high hopes of thus making the law serve as the guiding genius of our way of life.

I suppose that the construction of a law building means different things to different people as has the construction of great buildings of all times.

On occasions such as this, I am always reminded of the ancient story concerning the wayfarer who was passing a structure under construction. He stopped to inquire of the three craftsmen who were working on it what they were doing. The first, without looking up, responded, "I am making a living." The second said, "I am following my trade," but the third, rising to his full height and

* Chief Justice, United States Supreme Court. B.L., University of California, 1912, J.D., 1914. 
looking straight into the eyes of the stranger said, "Sir, I am building a temple."

I am sure that Dean Latty and his faculty who have such high aspirations for their already great law school, and the President and facuIty of the University who make it a vital part of Duke University, all believe that they are building a temple.

It is good to know that in this day and age when the physical sciences are the preoccupation of the world that American universities are concerned also with the development of law to cope with the changing conditions and the great social problems brought about by the application of science to every phase of life.

It is reassuring to know that the School of Law of Duke University is one of the few in our country which has established a "World Rule of Law Center" where scientific research is being made on questions of law and international organization bearing on security, peace, disarmament and world order. I trust it will not be long before every American university realizes that these subjects are today as fundamental as the law of property, torts and business. No country on the face of the earth-not even the great United States of America-can be secure until there is a world Rule of Law that is as well defined and as effectively enforced as that of our domestic law. We have made some progress in the development of the Rule of Law, but the progress has been painfully slow.

Up to the time of the American Revolution, the Rule of Law, as then understood in the English-speaking world, was confined practically to the Magna Charta (1215), Petition of Rights (1628), the Bill of Rights (1689), and the common law that had developed through their interpretation. In 1787, the Rule of Law was expanded, and for the first time was put into one written documentour Constitution. To further the concept of the Rule of Law, our own Bill of Rights was added to the Constitution by the First Congress of the United States which, by the way, was perhaps the greatest Congress which has ever met. Not only did it propose the Bill of Rights, but it established our federal judiciary. The Judiciary Act remains to this day with very little change, and it has served us well. That Congress also implemented our new Government, and provided the ingredients for our federalism that has been recognized as the genius of our American institutions. Our federalism has brought about more freedom of action on every level of Government 
with greater freedom of the individual than any system yet devised.

At that time life was simple. We were remote from the rest of the world. The idea of international law was in its infancy. Although Hugo Grotius (1583-1645) had already made his contribution to the cause of international law, by proclaiming that natural law prescribed rules of conduct for nations as well as individuals, it still was more of an ideal in the minds of a few people than a reality.

Since those days, we have moved forward in spite of the terrible wars we have had and the forebodings of the end of civilization by weapons of mass destruction. Now nations, large and small, do sit down at the conference table; they do have an opportunity to be heard. All decent people do reject the idea that might makes right. While we cannot say that the Rule of Law pervades the earth, we can say that all who believe in a free world think in terms of advancing that cause. Personally, I believe that in spite of all the dangers which face us-in spite of the intransigency in the world-we are moving forward and we have a right to believe that in the foreseeable future we will be able to avoid great wars. But the speed with which that can be done and the certainty with which it can be done depend on the attitude and approach made to the Rule of Law by everyone in this and every other free land.

Naturally, the phrase, "Rule of Law," means different things to the people of different lands. That term, as understood by us, was I believe well expressed by a special committee of the American Bar Association in a report prepared for the International Commission of Jurists in The Hague in 1958. The committee observed:

The 'Rule of Law' as a term in common usage by the disciples of Anglo-Saxon law is not susceptible of such precise definition as to carry the same meaning to all. For the purposes of the American analysis ... it is assumed to be the body of precepts of fundamental individual legal rights permeating institutions of government which are vested with appropriate power of enforcement and those procedures by which such precepts may be applied to make those rights effective. These elementsof precepts, institutions and procedures-exist in law to effect the protection of essential interests of the individual guaranteed by society through limitations on the authority of the state .... The precepts applied by our legislatures, executive agencies, courts and the bar are thereby recognized to be the basic law establishing fundamental legal rights. 
I believe something like that definition was in the minds of the members of our Court when they caused to be chiseled into the marble over the entrance to our Court Building the words, "Equal Justice Under Law."

However, we have a long way to go, both at home and abroad, before we can say, without fear of contradiction, that we do have equal justice under law. If we are to achieve that goal, our leaders must come from our law schools. Those are the places where the young men and women must not only learn to use the law to achieve just results in solving the affairs of life, but they must dedicate themselves to a belief that problems, large and small, can and should be decided through law. They should become a great breed whose preoccupation is not only with the mechanics of the law but with those great principles of justice and ethics and humanity that are implicit in it.

Sometimes I wonder if all our law schools are measuring up to such a concept of the law. We are wont to say that science is impersonal and that we are in danger of science destroying civilization. But is there not equally a great danger of destroying ourselves if the la'w becomes cold and indifferent and materialistic and without those humanitarian influences that have made it the sheet anchor of civilization? Too few of our law schools can find a place in their curriculum for such indoctrination. I know there are different ideas of approaching these subjects, and there are those who believe that students can be infused with such basic ideals by each professor in teaching the prescribed so-called practical legal subjects. I suppose that could be done. But human nature is such that it is not always done because specialization has a tendency to become myopic and to the extend that this kind of instruction is denied the students of the law, it is a weakness in our system.

Thousands of the graduates of law schools will eventually become judges, law professors and public servants, as well as private practitioners, and the contribution that each of them is capable of making depends on a true understanding of the Rule of Law. That term as we so often hear it expressed-that we have a government of laws and not of men-has been used so much in recent years that we sometimes utter it without really appreciating its true meaning. To one person it may mean one thing; to another it may have a quite different significance. And it is uncommon to find people who have 
a rounded concept of the Rule of Law. Too often we find people who believe fervently in that portion of the Rule of Law that protects them in their own sphere of activity but who are intolerant of that portion that protects other people in other circumstances of life. Many a person who believes implicity in the fact that the Constitution is designed to protect him in the enjoyment and use of his property, has little patience with those who insist on freedom of expression, freedom to teach, and freedom of association. Some believe ardently in the freedom of the press and of their right to protect their confidential source of information but have no regard for those who might claim the right against self-incrimination.

When we say we have a government of laws and not of men we mean, at the very least, that the law protects all men equally in their property and individual rights regardless of their race, religion, color or wealth. And even in America, where we have made great advances, we should not be complacent about the Rule of Law until we have first embraced and applied it at home and made it work in all its aspects. If we are honest with ourselves we must recognize that we are still working on a great unfinished job. This is our next and nearest step in developing a modern, adequate, legal system, and the attainment of this goal should be a primary purpose of the faculty and students in all schools of law.

In this time when the problem of building peace and averting nuclear war seems to overshadow every other question, there are those who are skeptical about the value of the contribution to be made in law schools and the usefulness of legal research. There are people who feel that the physical sciences have so far outstripped the social sciences that our civilization is in danger of utter destruction because of a lack of the moral force necessary to control science. They are afraid of science. It seems to me that this carries an implication that scientists are less concerned with the welfare of the world than are the rest of us. I do not believe this is true.

When the chemists of the last century worked out by careful experiments the nature and properties of chlorine, I do not believe they had in mind the use of chlorine gas to exterminate massed soldiery, as happened on the battle fields of Europe in World War I.

When Albert Einstein at the turn of the century worked out his 
famous mathematical formula equating mass with energy, I do not believe he had military uses of atomic energy in mind.

When Ernest Lawrence built his first cyclotron on the hill back of Berkeley and successfully split the atom, I am positive that the atomic explosion at Hiroshima was not in his thoughts.

It is not the scientists who are the ogres of our time and it is not science that is running away and endangering civilization. The danger lies in the lack of a lawful world and the absence of a world ordered under law which will avoid the pressures to use scientific knowledge for destructive rather than for peaceful purposes.

It would be better if, instead of worrying about the advancement of scientific knowledge, we gave more consideration to applying some of the techniques that make science so powerful to the furtherance of the Rule of Law and the controls and self-restraint that will make the wartime applications of scientific knowledge obsolete.

In all countries and from the beginning of literature, it is traditional to express our ideas about education, the pursuit of knowledge and progress towards ideals by analogy to the sun and to the mysteries of light, and probably such analogies are no less useful today. Recently the physical scientists have produced a most extraordinary invention which will produce a beam of what they call "coherent light," a kind of light never found in nature and never before seen in the world. The device is called an "Optical Maser." The principle was discovered by Charles $\mathrm{H}$. Townes at Columbia University, and the word "Maser" derives from the key letters in the phrase, "microwave amplification by stimulated emission of radiation."

In this fascinating device by the application of electrical power, atoms are reflected and bounced back and forth within a tube reaching a crescendo from which a cascade of photons emerges in a beam of light in which each wave is precisely in step with its pred. ecessor, each wave thus adding to the power of the wave which has gone before. Because these waves are all in step, each adding to the force of the other, a beam of light of incredible power can be produced. The Optical Maser has actually flashed a spot of red light on the surface of the moon which could be observed with telescopes on earth. At present, not even the scientists can estimate the potential usefulness of this device.

On this analogy I suggest that our law schools could well become a kind of Maser for the Rule of Law. Within their walls the ele. 
mental principles of law and justice should be broken down and reflected and re-reflected, striking sparks from students and faculty alike, and this mixture with adequate stimulation should produce a beam of coherent legal light of immense power and capable of revealing the Rule of Law in its full glory to any and every part of the earth.

We must not be led astray by the notion that legal research is limited to puttering among dusty books in order to amplify some morsel of academic learning which is of interest to but a handful of other scholars. The meaning of legal research must be broadened to include basic research on the jurisprudence of world Rule of Law, the exploitation of new sources of international law, and the creation of new concepts of international law, creative, intellectual efforts in designing and improving international institutions, the provision of teaching materials and new kinds of courses, and supplying materials to educate and influence public opinion in all parts of the world. Wave after wave of research in these fields emerging from our law schools would be a beam of coherent legal light and a powerful engine in spreading the Rule of Law and building peace through law.

The same kind of research must be done on our domestic affairs. Do you believe it is being done today? I venture to say that it is not.

Having said that the law is slow to advance; that we of the profession are not exploring the legal problems of the day with the same zeal that scientists probe the mysteries of light, sound, space, and fission, I suppose it would be lawyer-like to now give a bill of particulars. This is not the time nor place to recount all of our shortcomings, but it should not be out of place to give at least one glaring example of what I have in mind. In December of last year, a committee of state legislators, acting through the Council of State Governments, recommended to the Legislatures of all the States of the Union that they adopt a never-before-used alternative route (under Article V) to amend the Constitution of the United States in three respects:

1. To take away from the federal courts all jurisdiction in state legislative apportionments;

2. To establish a court composed of the 50 Chief Justices of the States, with power to overrule the Supreme Court of the United States in cases involving federal-state relationships, and 
3. To change the amending process so as to practically supplant the Congress of the United States in favor of the Legislatures of the States.

It must be apparent to all that these proposed Constitutional Amendments would radically change the character of our institutions.

I shall not at this time argue the merits or demerits of any of these proposals. I merely point out that, if adopted, they would make profound changes in the judiciary, the relationship between the federal and state Governments, and even the stability of the United States Constitution.

I suppose there are some, perhaps many, in this audience who have never heard of these proposals. And that is not surprising because so little public mention has been made of them. Yet in 24 States of the Union, one or both Houses of the Legislature have adopted one or two or even all three of these proposals. It has been accomplished with little or no debate and with practically no recognition by the Bar of America.

In preparation for this occasion, I researched the publications in the Supreme Court Library and in the Library of Congress. This included all the law reviews in the country, all the legal periodicals and the publications of all the legal societies. The net result of that search was one article in the Yale Law Journal for April by Professor Charles L. Black of that Law School. Not another recognition of these drastic changes in our Government was to be found in any of these legal publications which are designed to alert, not only the members of the Bar, but the public at large to the legal problems confronting us. If proposals of this magnitude had been made in the early days of the Republic, the voices of the lawyers of that time would have been heard from one end of our land to the other. The great debate would be resounding in every legislative hall and in every place where scholars and statesmen gather. Surely the problems of America are as great today as they were in those days. Surely the Constitution should be as precious to us now as it was then. If lawyers are not to be the watchmen for the Constitution, on whom are we to rely?

Let us hope that in this new law center which we dedicate today, and in all the law schools of America, there will be a constant awareness of the fact that vigilance is the price we must always pay for our cherished freedoms. 